\title{
López Mills, Tedi. (2009) Muerte en la rúa Augusta. México: Editorial Almadía.
}

Jorge Aguilera López

FFyL-UNAM

Luego de años de trabajo como oficinista, el señor Gordon Smith pierde la razón, el empleo y finalmente la vida después de pasar sus últimos días en el jardín de su casa, junto a la alberca, a las afueras de Fullerton, California. O tal vez, todo ocurrió mientras caminaba en Lisboa por la rúa Augusta. Entre uno y otro escenario, transcurre la historia que nos cuenta Tedi López Mills, no obstante que estemos leyendo un poema o una colección de poemas o un relato poetizado. $Y$ es que las indefiniciones, los descentramientos y la mixtura genérica son los principales elementos que encontramos a cada página de este libro, con el que la autora ganó el premio Xavier Villaurrutia 2009.

Poema narrativo. Así anuncia la contraportada el contenido de este texto, y al momento de leerlo confirmamos tal aserto: se nos cuenta una historia, con una trama más o menos clara, con una secuencia temporal y personajes definidos. Hasta allí, la segunda parte de la oferta, la narratividad, está asegurada. Pero, ¿qué ocurre con la poesía? El lenguaje, en principio sencillo, ofrece momentos líricos de gran efectividad enunciados por la voz del personaje Gordon, el cual mantiene en la indefinición al texto, al ser un "loco" quien guía la poeticidad del libro: ¿leemos un discurso irracional que, sólo por contagio, asociamos con la poesía, o leemos un lenguaje poético disfrazado de irracionalidad? La pregunta se vuelve pertinente al pensar en el grado de control que se impone en la elaboración verbal del texto, pues si el lenguaje lírico nace de la irracionalidad, estamos frente a una concepción de la poesía distinta a aquella que sugiere el poema como entidad controlada por el sujeto creador.

Como sea, la principal discusión alrededor de Muerte en la rúa Augusta estriba en la posibilidad del poema por contar una historia. En este sentido, la tradición mexicana, escasa en esta opción, se nutre sin duda de la apuesta de López Mills por ensanchar sus posibilidades, por vía de la poesía anglosajona (pensemos en T. S. Eliot o William Carlos Williams), pero al mismo tiempo constituye una evidencia de las fronteras textuales a las que se ha acercado la poesía en los últimos tiempos. Nos encontramos entonces ante un libro que supera la estricta separación de los géneros para aprovechar lo mejor de dos mundos, el lírico y el narrativo, con la intención de ofrecernos una experiencia de lectura enriquecedora y actual.

La casi natural identificación del personaje principal, el señor Gordon, con la figura del escritor se da a partir de la existencia de tres cuadernos en que 
todo lo relevante para la historia se hace presente: "un cuaderno azul (de las albercas) / uno blanco (de los dibujos) / y uno verde (su diario)." A través de ellos seguimos las peripecias de Gordon y de ese alter ego que resuena en su cabeza: Anónimo, voz interior que desdobla la personalidad del protagonista y le "dicta" las frases más claras que anotará en su diario:

Abajo metes las frases con orden, comas, puntos, sin tachones:

todo lo que puedas de Donna, mañas, trucos, te pisa, te quita tu dinero, te pega con el trapo, con Ralph susurra en la cocina mientras arreglas la mesa, y luego escribe algún pensamiento, alguna imagen noble, hermosa, sobre la naturaleza de los jardines y de las personas; ahí es donde yo te dictaré.

Esta voz doble del personaje es además una puerta de entrada a la confusión permanente en que Gordon se encuentra sumido y es la que nos lleva a descentrar la lectura narrativa hacia lo poético, habida cuenta que los "huecos" entre las frases sencillas son llenados por los dictados de Anónimo ("Anónimo le enseñó a Gordon varias cosas, / por ejemplo, cómo rellenar los huecos entre 'saqué la basura...salí al jardín '"), pero también a que el uso más anómalo del lenguaje en el libro se da al nivel sintáctico, en la alteración de la correspondencia gramatical, y esos momentos surgen en el diálogo de ambas voces:

- ¿Cómo sabes que estás donde estás?

[...]

-Porque sé que lo estoy, me miro a mí mismo.

- ¿Te miras? ¡Ja!

- ¿Cómo sabes que eres tú?

-Porque estoy dentro de mí.

- ¿Quién es mí?

-Yo.

- ¿Quién?

-Yo.

- ¿Y mí?

—No te burles, Anónimo, me estás confundiendo, quiero meterme a la casa. —No. Demuéstrame que eres tú 
y que estás donde estás.

-No.

—Yo soy tú, Gordon, y Mí eres yo.

Por contraste, Donna y Ralph, la esposa y el mejor amigo de Gordon, se nos presentan como antagonistas por partida doble: en el sentido canónico de personajes contrapuestos al principal, pero también como voz de la conciencia racional que busca encausar la conducta de Gordon por el camino permisible: "Un día Donna le pide / a Gordon que aprenda a fingir, / se le nota cada cosa / que siente en la cara, / le dice, / es de mala educación / [...] / ¿todos lo hacen?, pregunta Gordon, / Todos salvo tú". De esta manera, el hilo narrativo destaca una tensión entre conductas dicotómicas (locura-hipocresía) mediante la cual se enhebra una historia circular: Donna y Ralph buscan el dinero de Gordon, quien asevera esconderlo "al fondo de mi alberca", que no es "la alberca de todos" - la que se encuentra en el jardín — sino una de las que tiene dibujadas en su cuaderno azul; ante esta respuesta, la pareja sigue preguntando y el protagonista asegurando que el paradero es el mismo. Círculo que no se cierra, salvo que uno u otro polo estén dispuestos a acceder a las premisas del contrario, que es justo donde reside el nudo gordiano de la dicotomía.

Uno más de los estímulos para la lectura reside en el aspecto visual del libro como objeto. Entre el texto y las ilustraciones encontramos una correspondencia que, sin embargo, no podemos aseverar que sea deliberada, dado que no hay indicación alguna sobre la autoría del diseño gráfico del libro; por tanto, no podemos conocer el grado de relación existente entre la autoría del texto y de las imágenes, pero es innegable el estimulo que suponen al momento de la lectura. Apenas miramos la portada, y entendemos que en nuestras manos tenemos un cuaderno (¿el blanco o el verde?) que al avanzar por las páginas nos enteramos puede ser uno de los de Gordon. Al mismo tiempo, observamos las albercas y los dibujos entreverados con el relato del su diario. Una primera conclusión nos puede hacer pensar en la integración orgánica del texto, las imágenes y el objeto libro como una propuesta estética; pero apenas notamos las evidentes disociaciones de verosimilitud entre texto e imágenes (por ejemplo, el personaje, que nunca ha salido de California, no podría escribir en español, idioma en que están escritos los textos de los dibujos) recordamos la clase de materia verbal frente a la que nos encontramos: un híbrido que constantemente rompe nuestras expectativas en relación con el tipo de texto que leemos.

En suma, Muerte en la rúa Augusta se nos ofrece como un libro donde la poesía es apenas el inicio de una experiencia de lectura que por la vía de la narratividad nos acerca a un juego donde la literatura ensancha su oferta. El dato factual que la propia Tedi López Mills ofrece para entender el germen del texto (al caminar 
ella por la rúa Augusta, en Lisboa, presenció la muerte de un turista alemán) pasa a segundo plano, y concentramos la lectura en las estrategias utilizadas por la autora para resolver el enigma ya no de la muerte del personaje, que se anuncia desde el inicio, sino de la manera en que se llegó a dicho acto. Si lo narrativo le gana la partida a la poesía, que parece ser el caso, es menester señalarlo, pero también se vuelve necesario aceptar que, mediante la mixtura, López Mills propone una nueva forma de acceder a las posibilidades poéticas contemporáneas. Lejos ya de los grandes discursos líricos que pretenden detentar la razón metafísica suprema, lo que sea que ello signifique, este libro cuenta una historia que en realidad no resuelve nada: el personaje que aparece muerto junto a su alberca, en el apartado inicial, es el mismo que cae muerto en la rúa Augusta al final del texto. ¿Inconsistencia en la verosimilitud u otra estrategia más de indefinición? Como sea, la sentencia ha sido anunciada desde el pórtico: Anónimo dijo: "esto ni se lee ni se entiende". Y en ese no entender quedamos entrampados, aunque no por ello frustrados. Quizá el leer sea un primer camino a la comprensión, y este libro sin duda requiere una lectura acorde con su propuesta: descentrar la idea para acceder al sentido, y descolocar las preconcepciones para experimentar la lectura. 